\author{
MINERALOGIA POLONICA \\ 10.2478/v10002-007-0006-9 \\ PL ISSN 0032-6267 \\ Vol. 37, No 1, 2006
}

Jarosław MAJKA', Bartosz BUDZYŃ ${ }^{2}$

\title{
MONAZITE BREAKDOWN IN METAPELITES FROM WEDEL JARLSBERG LAND, SVALBARD - PRELIMINARY REPORT
}

\author{
Received 5 November 2005; accepted 25 April 2006
}

A b stra ct. Metapelites from the SW part of Wedel Jarlsberg Land were progressively metamorphosed under amphibolite facies conditions followed by a Caledonian low-temperature metamorphic event under greenschist facies conditions. The latter resulted in various stages of monazite breakdown. These include monazite alterations and the formation of allanite-apatite coronas.

Key-words: allanite, monazite breakdown, metapelites, Isbjørnhamna Group, Svalbard

\section{INTRODUCTION}

Monazite and allanite are relatively common REE-rich accessory minerals in metapelites. Monazite, and allanite, grows during metamorphism (e.g., in Barrovian-type metamorphic terrains). Metamorphic allanite is generally stable under upper-greenschist facies conditions (above Bt-in isograde; Ferry 2000). Allanite disappearance and the formation of new metamorphic monazite is related to prograde metamorphism under amphibolite facies conditions (e.g., Ferry 2000; Catlos et al. 2002; Wing et al. 2003; Gieré, Sorensen 2004). It is also well known that the monazite-to-allanite replacement takes place under low-temperature metamorphic conditions (e.g., Michalik, Skublicki 1998; Ferry 2000).

In this paper, we describe the replacement of monazite in metapelites by allanite-apatite coronas. These coronas probably formed during a greenschist-facies metamorphic event.

1 AGH, University of Science and Technology, Department of Mineralogy, Petrography and Geochemistry, al. Mickiewicza 30, 30-059 Kraków, Poland; jmajka@poczta.fm

2 Jagiellonian University, Institute of Geological Sciences; Oleandry 2a, 30-063 Kraków, Poland; budzyn@geos.ing.uj.edu.pl 


\section{GEOLOGICAL BACKGROUND}

The Caledonian crystalline basement, the so-called Hecla Hoek Succesion, crops out along the western and northern coasts of the Svalbard archipelago. An exotic neoproterozoic tectonic block, surrounded by the Caledonian basement rocks, has been distinguished in the SW part of Wedel Jarlsberg Land located between Austre Torellbreen and Hornsund Fjord in the southern part of the island of Vestspitsbergen (Czerny et al. 1993; Fig. 1; Majka et al. 2006). This tectonic block comprises a well-stratified metasedimentary complex known as the Isbjørnhamna Group which is overlain by meta-volcanosedimantary rocks of the Eimfjellet Group (Birkenmajer 1958, 1992; Czerny et al. 1993). The rocks of the Isbjørnhamna Group were progressively metamorphosed under amphibolite-facies conditions. This was followed by a Caledonian low-temperature greenschist-facies metamorphic event (Smulikowski 1960, 1965; Czerny et al. 1993; Manecki et al. 1997; Majka et al. 2004).

The Isbjørnhamna Group rocks include mica schists, paragneisses, calc-silicate rocks and marbles. Three formations have been distinguished within the Isbjørnhamna Group: the Skoddefjellet Fm., the Ariekammen Fm. and the Revdalen Fm. (Birkenmajer 1958, 1992).

The Skoddefjellet Fm., the lowermost part of the Isbjørnhamna Group, comprises mica schists and paragneisses. The overlaying Ariekammen Fm. is composed of marbles and garnet-bearing calcite-mica schists with relatively thin intercalations of Skoddefjellet-type mica schists and paragneisses. The Revdalen Fm., the uppermost part of the Isbjørnhamna Group, is a uniform complex of mica schists (Smulikowski 1960; Czerny et al. 1993; Majka et al. 2004).

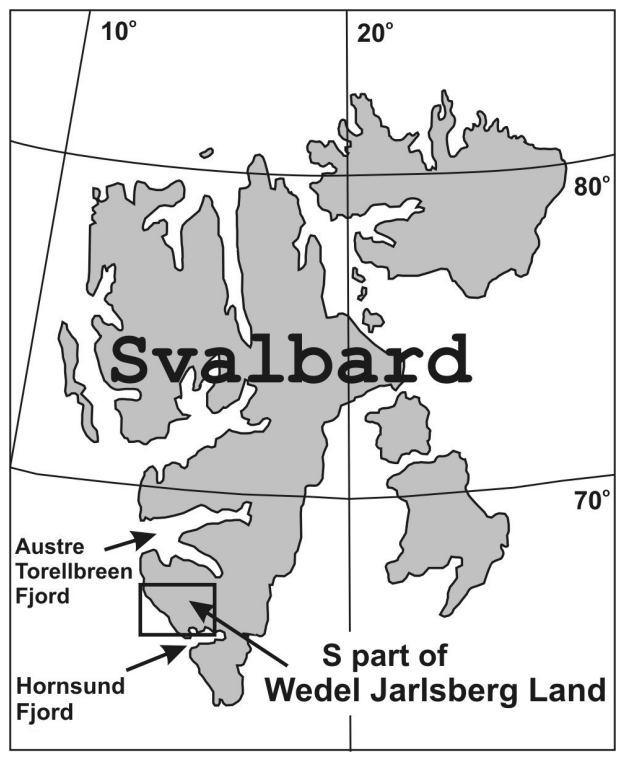

Fig. 1. Sketch map of the Svalbard Archipelago in the SW part of Wedel Jarlsberg Land. Sampled region is within rectangle 


\section{SAMPLE SELECTION AND METHODS OF INVESTIGATION}

Samples were collected from the Skoddefjellet Fm. and from the Revdalen Fm. Garnet-bearing mica schists from both formations that had been only slightly affected by the Caledonian metamorphic event were chosen for analyses.

Mineral chemical compositions were determined by field emission scanning electron microscopy (Hitachi S-4700 microscope coupled with a NORAN Vantage energy dispersive spectrometer). The FESEM-EDS analyses were performed in the Laboratory of Field Emission Scanning Electron Microscopy and Microanalysis at the Institute of Geological Sciences of the Jagiellonian University, Kraków. Operating conditions were as follows: accelerating voltage $20 \mathrm{kV}$, counting time 400 seconds and a beam diameter of $<1 \mu \mathrm{m}$ focused on polished thin sections coated with carbon.

\section{RESULTS}

Metapelite petrography and mineral composition

The metapelites belonging both to the Skoddefjellet Fm. and to the Revdalen Fm. are fine-grained mica schists with scattered porphyroblasts of garnet, staurolite and biotite. Typically, the earlier progressive mineral assemblage of the Isbjørnhamna Group metapelites is quartz + biotite \pm muscovite \pm garnet \pm chlorite \pm plagioclase. Accessory tourmaline, zircon, sphene, apatite, ilmenite, hematite and magnetite are common. Additionally, kyanite, kyanite + staurolite, staurolite or chloritoid occur in some. Monazite and/or allanite occur in most metapelites. An additional REE-bearing mineral, xenotime, and unidentified Th-phases were also found in some metapelites. Changes due to the later low-temperature metamorphism include the partial or complete replacement of garnet and biotite by chlorite, sericitization of plagioclase and kyanite and disintegration of muscovite. Selected FESEM-EDS analyses are presented in Table 1.

Accessory REE-bearing minerals

Monazite

Monazite is present as subhedral to anhedral chemically unzoned grains up to $c a$ $50 \mu \mathrm{m}$ long (Figs 2-4). Although monazite commonly occurs as single grains, intergrowths with xenotime also occur (Fig. 4). Some grains are surrounded by aggregates of tiny apatite grains or apatite-allanite coronas. Epidote may be present in the latter. Monazite grains $<10 \mu \mathrm{m}$ are typically almost completely replaced by apatite and allanite (e.g., samples Sp-111/02, Sp-219/03). 
TABLE 1

Selected FESEM-EDS analyses (in wt\%) of monazite (Mnz), allanite (Aln), xenotime (Xt) and apatite (Ap)

\begin{tabular}{||c|c|c|c|c|c|c||}
\hline $\begin{array}{c}\text { Component } \\
{[\mathrm{wt} \%]}\end{array}$ & $\begin{array}{c}\mathrm{Mnz} \\
111-1\end{array}$ & $\begin{array}{c}\mathrm{Mnz} \\
214 \mathrm{~A}-2\end{array}$ & $\begin{array}{c}\mathrm{Aln} \\
219-3\end{array}$ & $\begin{array}{c}\mathrm{Aln} \\
111-1\end{array}$ & $\begin{array}{c}\text { Xt } \\
214 \mathrm{~A}-2\end{array}$ & $\begin{array}{c}\text { Ap } \\
111-1\end{array}$ \\
\hline \hline $\mathrm{SiO}_{2}$ & 3.12 & 3.27 & 34.07 & 32.69 & 1.72 & 2.41 \\
\hline $\mathrm{Al}_{2} \mathrm{O}_{3}$ & 0.56 & 1.10 & 16.99 & 16.39 & 2.50 & 0.53 \\
\hline $\mathrm{P}_{2} \mathrm{O}_{5}$ & 30.55 & 33.45 & n.d. & 2.19 & 38.02 & 36.72 \\
\hline $\mathrm{CaO}$ & 1.10 & 0.81 & 11.40 & 11.27 & n.d. & 54.65 \\
\hline $\mathrm{FeO}_{\mathrm{TOT}}$ & n.d. & n.d. & 12.95 & 14.58 & n.d. & n.d. \\
\hline $\mathrm{MgO}$ & n.d. & n.d. & 0.26 & n.d. & n.d. & n.d. \\
\hline $\mathrm{MnO}$ & n.d. & n.d. & 0.44 & n.d. & n.d. & n.d. \\
\hline $\mathrm{La}_{2} \mathrm{O}_{3}$ & 10.98 & 12.12 & 4.14 & 4.03 & n.d. & 0.78 \\
\hline $\mathrm{Ce}_{2} \mathrm{O}_{3}$ & 30.28 & 29.35 & 10.73 & 9.49 & n.d. & 2.26 \\
\hline $\mathrm{Pr}_{2} \mathrm{O}_{3}$ & 4.31 & n.d. & 1.17 & 1.50 & n.d. & 0.46 \\
\hline $\mathrm{Nd}_{2} \mathrm{O}_{3}$ & 12.71 & 10.13 & 4.06 & 4.37 & n.d. & 0.76 \\
\hline $\mathrm{Sm}_{2} \mathrm{O}_{3}$ & 0.82 & 2.54 & 0.95 & 0.40 & n.d. & n.d. \\
\hline $\mathrm{Gd}_{2} \mathrm{O}_{3}$ & n.d. & 2.41 & 0.84 & n.d. & n.d. & n.d. \\
\hline $\mathrm{Dy}_{2} \mathrm{O}_{3}$ & n.d. & n.d. & n.d. & n.d. & 4.43 & n.d. \\
\hline $\mathrm{Er}_{2} \mathrm{O}_{3}$ & n.d. & n.d. & n.d. & n.d. & 6.16 & n.d. \\
\hline $\mathrm{Yb}_{2} \mathrm{O}_{3}$ & n.d. & n.d. & n.d. & n.d. & 5.03 & n.d. \\
\hline $\mathrm{Y}_{2} \mathrm{O}_{3}$ & n.d. & n.d. & 0.33 & 0.28 & 40.75 & n.d. \\
\hline $\mathrm{ThO}_{2}$ & 4.66 & 4.21 & 1.80 & 2.08 & 0.74 & 1.43 \\
\hline $\mathrm{UO}_{2}$ & 0.90 & 0.60 & n.d. & 0.37 & 0.64 & n.d. \\
\hline $\mathrm{PbO}_{2}$ & n.d. & n.d. & n.d. & 0.36 & n.d. & n.d. \\
\hline $\mathrm{Cl}$ & 100.00 & 100.00 & 100.00 & 100.00 & 100.00 & 100.00 \\
\hline $\mathrm{Total}$ & & & & & n.d. \\
\hline
\end{tabular}

n.d. - not determined.

\section{Xenotime}

Xenotime, not as common as monazite, occurs in two forms - rounded grains $<20 \mu \mathrm{m}$ long and/or as intergrowths with monazite (Fig. 4). The xenotime grains are chemically unzoned. Significant amounts of this mineral occur as inclusions $(<15 \mu \mathrm{m}$ in size) in garnets. Xenotime is also associated with Th-phases. The xenotime-monazite intergrowths are rimmed by allanite.

64 
REE-bearing apatite

REE-bearing apatite occurs only as tiny grains $(<2 \mu \mathrm{m}$ in diameter) in aggregates forming the reaction coronas mantling monazite (Figs 2, 3). Apatite contains $<4.1 \mathrm{wt} \%$ REE oxides and $<1.4 \mathrm{wt} \% \mathrm{ThO}_{2}$.

Allanite

Allanite occurs in two ways. Usually the mineral forms rims with apatite around monazite- or monazite and xenotime intergrowths (Figs 2, 3, 4). This rim-forming

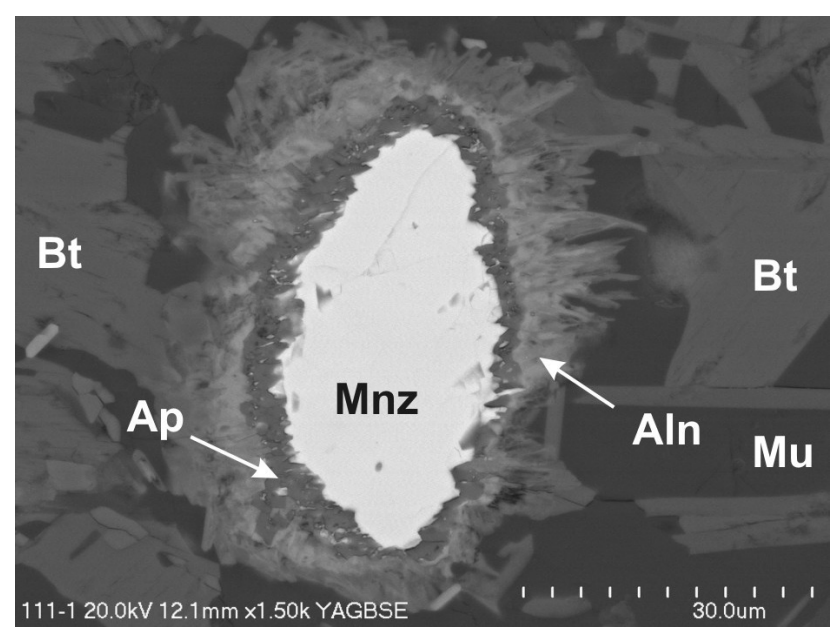

Fig. 2. FESEM-BSE image of monazite with apatite-allanite corona (sample Sp-111/02). Aln - allanite, $\mathrm{Ap}$ - apatite, $\mathrm{Bt}$ - biotite, $\mathrm{Mnz}$ - monazite, $\mathrm{Mu}$ - muscovite

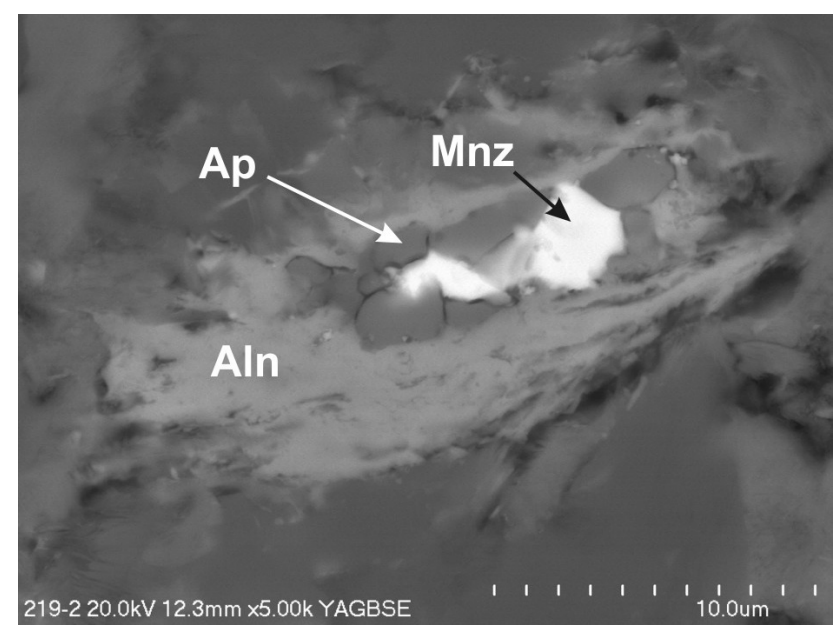

Fig. 3. FESEM-BSE image showing monazite alteration with formation of apatite and allanite (sample Sp-219/03). Aln - allanite, Ap - apatite, Mnz - monazite 


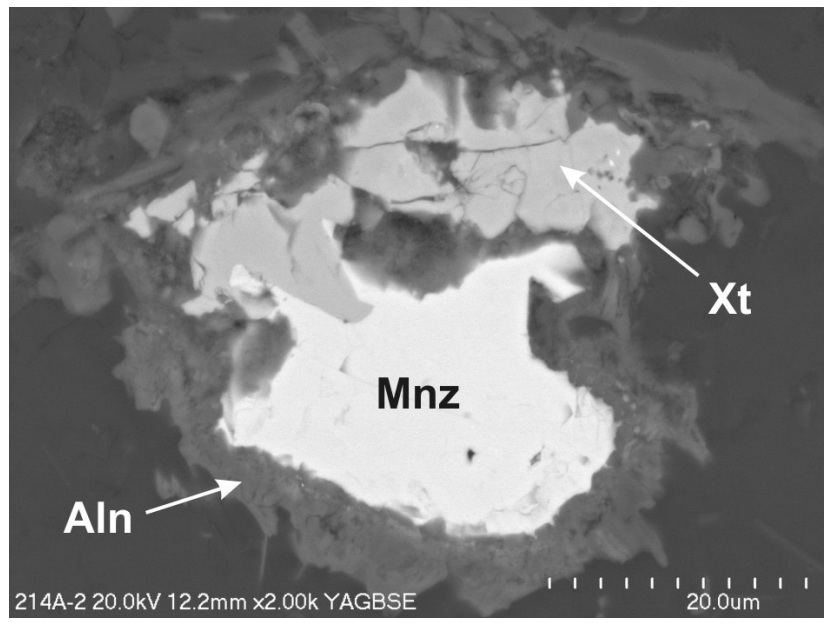

Fig. 4. FESEM-BSE image of monazite and xenotime intergrowth rimmed by allanite corona (sample Sp-214A/03)

Aln - allanite, Mnz - monazite, $\mathrm{Xt}$ - xenotime

allanite does not respect previous monazite morphologies and fills spaces and cracks within surrounding minerals. Allanite forming subhedral prisms dispersed in rock represents a second mode of occurrence Additionally, one inclusion of allanite associated with dispersed xenotime and Th-phases grains $(<4 \mu \mathrm{m}$ in diameter $)$ was observed in garnet (Fig. 5). Moreover, this allanite contains inclusions of epidote and abuts with quartz and chlorite filling garnet fractures.

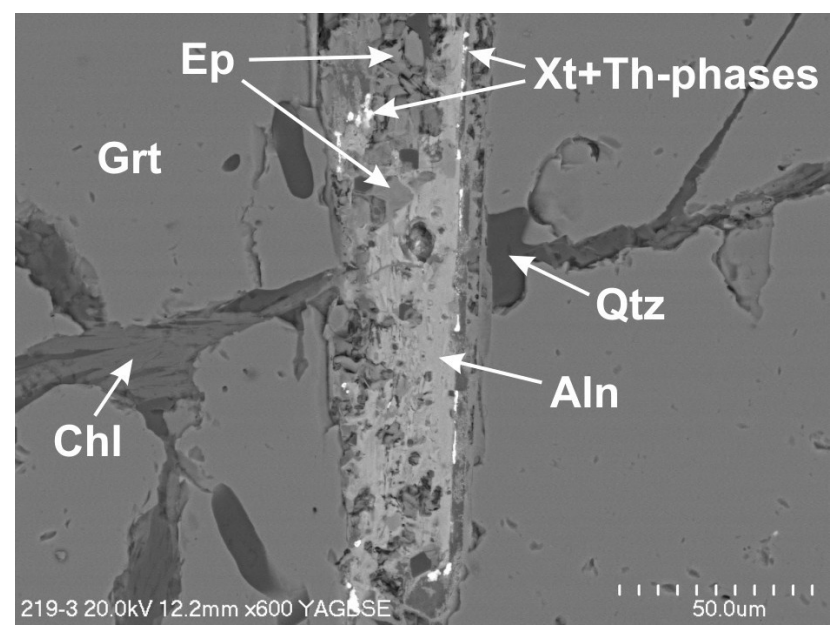

Fig. 5. FESEM-BSE image of allanite inclusion overgrown by xenotime and Th-phases in garnet (sample Sp-219/03).

Aln - allanite, Chl - chlorite, Ep - epidote, Grt - garnet, Qtz - quartz, Xt - xenotime 


\section{DISCUSSION}

The lack of chemical zonation in the monazite grains indicates a metamorphic origin for this mineral. According to Ferry (2000), such monazite can grow during progressive metamorphism under amphibolite-facies conditions.

Different degrees of alterations characterize monazite grains of different sizes. Apatite-allanite coronas form on grains $>30 \mu \mathrm{m}$ in size whereas, with monazite grains $<10 \mu \mathrm{m}$, alteration is typically almost complete. Volumetrically, each monazite grain appears to have suffered the same degree of alteration. However, this is not always so; all degrees of alteration were observed in one sample (Sp-219/03).

According to Wing et al. (2003), allanite-forming reactions in metapelites are driven by aqueous fluid infiltration. These reactions are similar to monazite-breakdown reactions during amphibolite-facies metamorphism of granitic rocks from the Eastern Alps and in orthogneisses from the Western Carpathians (Finger et al. 1998; Broska, Siman 1998). Broska and Siman (op.cit.) proposed the following reaction:

$$
\begin{aligned}
& \left.\underset{\text { (monazite) }}{3 \mathrm{REE}\left[\mathrm{PO}_{4}\right]}+\underset{\text { (annite) }}{\mathrm{KFe}_{3}\left[(\mathrm{OH}, \mathrm{F})_{2}\right.} \mid \mathrm{AlSi}_{3} \mathrm{O}_{10}\right]+\underset{\text { (plagioclase) }}{4 \mathrm{Ca}\left[\mathrm{Al}_{2} \mathrm{Si}_{2} \mathrm{O}_{8}\right]+\underset{\text { (quartz) }}{3 \mathrm{SiO}_{2}}+\underset{\text { (in fluid) }}{4 \mathrm{Ca}^{2+}}+\mathrm{H}^{+}} \leftrightarrow
\end{aligned}
$$

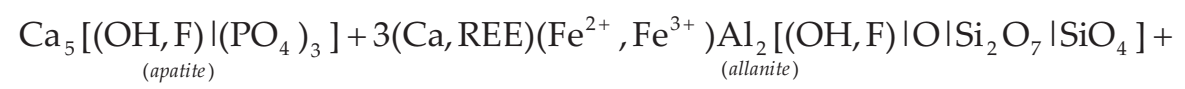

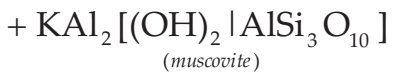

The investigated monazite grains revealed alterations similar to those described by Finger et al. (1998) and Broska and Siman (1998). The allanite-forming reaction (Figs 2,3) may have occurred in a "gel-form" with apatite nucleating on monazite rims (Broska and Siman 1998). Moreover, a supply of $\mathrm{Ca}^{2+}$ and $\mathrm{H}^{+}$in fluids was probably necessary. Thus, the apatite ring of the corona alteration may have been the medium for REE transfer from the altering monazite to the outermost allanite ring.

The allanite inclusion which perpendicularly crosscuts cracks in garnet (Fig. 5; sample Sp-219/03), and the retrogressive secondary chlorite which fills these cracks, suggest that two distinctly different overprinting events affected the garnet and its rock.

\section{CONCLUSIONS}

1. Monazite in metapelites from the SW part of Wedel Jarlsberg Land displays various degrees of breakdown and, as a consequence, of allanite formation. The monazite 
is probably related to neoproterozoic progressive metamorphism under amphibolite-facies conditions (Majka et al. 2006).

2. Monazite alterations and the formation of allanite-apatite coronas are probably related to low-temperature Caledonian metamorphism. Further investigation is necessary to detail the reactions that resulted in the formation of allanite and to determine the age of the metamorphic event during which those alterations occurred.

Acknowledgements. This manuscript greatly benefited from help and discussions with Prof. Andrzej Manecki and Dr. Jerzy Czerny. Dr. Igor Broska and Dr. Marek Michalik are also acknowledged for their constructive comments. Prof. P. Kennan is gratefully acknowledged for his review of this manuscript and corrections in English text. This research was partially funded by AGH-UST research grant no. 10.10.140.180 and the Jagiellonian University research fund.

\section{REFERENCES}

BIRKENMAJER K., 1958: Preliminary report on the stratigraphy of the Hecla Hoek Formation in Wedel Jarlsberg Land, Vestspitsbergen. Bulletin de l'Académie Polonaise des Sciences, Série des sciences des chim., geol., geogr. 6 (2), 143-150.

BIRKENMAJER K., 1992: Precambrian Succession at Hornsund, south Spitsbergen: a lithostratigraphic guide. Studia Geologica Polonica 98, 7-66.

BROSKA I., SIMAN P., 1998: The breakdown of monazite in the West-Carpathian Veporic orthogneisses and Tatric granites. Geologica Carpathica 49, 161-167.

CATLOS E. J., GILLEY L. D., HARRISON T. M., 2002: Interpretation of monazite ages obtained via in situ analysis. Chemical Geology 188, 193-215.

CZERNY J., KIERES A., MANECKI M., RAJCHEL J. (MANECKI A., ed.), 1993: Geological map of the SW part of Wedel Jarlsberg Land, Spitsbergen 1:25000. Institute of Geology and Mineral Deposits, Cracow, $61 \mathrm{pp}$.

FERRY J. M., 2000: Patterns of mineral occurrence in metamorphic rocks. American Mineralogist 85, 1573-1588.

FINGER F., BROSKA I., ROBERTS M. P., SCHERMAIER A., 1998: Replacement of primary monazite by apatite-allanite-epidote coronas in an amphibolite facies granite gneiss from the eastern Alps. American Mineralogist 83, 248-258.

GIERÉ R., SORENSEN S. S., 2004: Allanite and Other REE-Rich Epidote-Group Minerals. Reviews in Mineralogy and Geochemistry 56, 431-493.

MAJKA J., BUDZYŃ B., CZERNY J., MANECKI M., 2006: REE accessory minerals as regional metamorphic processes indicators: an example from Wedel Jarlsberg Land, Svalbard. Geolines 20, 88-89.

MAJKA J., CZERNY J., MANECKI M., 2004: Petrographical characteristics of the Isbjørnhamna Group Rocks (Wedel Jarlsberg Land, Spitsbergen). Polskie Towarzystwo Mineralogiczne - Prace Specjalne 24, 279-282.

MANECKI M., HOLM D. K., CZERNY J., LUX D, 1997: Thermochronological evidence for late Proterozoic (Vendian) cooling in southwest Wedel Jarlsberg Land, Spitsbergen. Geological Magazine 135 (1), 63-69.

MICHALIK M., SKUBLICKI Ł., 1998: Breakdown of monazite during alterations of the High Tatra granitoids. Polskie Towarzystwo Mineralogiczne - Prace Specjalne 11, 145-147 (in Polish).

SMULIKOWSKI W., 1960: Preliminary Report on the Petrology of the Isbjørnhamna Formation (Hornsund Area, Vestspitsbergen). Bulletin de l'Académie Polonaise des Sciences, Série des sciences des chim., geol., geogr. 8 (3), 159-163.

SMULIKOWSKI W., 1965: Petrology and some structural data of lower metamorphic formations of the Hecla Hoek Succession in Hornsund, Vestspitsbergen. Studia Geologica Polonica 18, 1-107. 
WING B., FERRY J.M., HARRISON T.M., 2003: Prograde destruction and formation of monazite and allanite during contact and regional metamorphism of pelites: petrology and geochronology. Contributions to Mineralogy and Petrolology 145, 228-250.

Jarosław MAJKA, Bartosz BUDZYŃ

ROZPAD MONACYTU W METAPELITACH Z ZIEMI WEDELL JARLSBERGA, SVALBARD - WSTĘPNE WYNIKI BADAŃ

Streszczenie

Wykonane badania metapelitów z SW części Ziemi Wedel Jarlsberga przy zastosowaniu metod FESEM-EDS wykazały różne stadia rozpadu monacytu i formowania allanitu. Przeobrażenia monacytu powstałego na etapie progresywnego metamorfizmu $\mathrm{w}$ warunkach facji amfibolitowej oraz geneza koron reakcyjnych na tym minerale (złożonych z allanitu i apatytu) są związane najprawdopodobniej z późniejszym niskotemperaturowym etapem metamorfizmu (warunki facji zieleńcowej) podczas orogenezy kaledońskiej. 